\section{Transfusion Medicine and Hemotherapy}

\section{Review Article - Übersichtsarbeit}

Received: April 11, 2006

Accepted: July 19, 2006

Published online: September 18, 2006

\title{
Transfusion Medicine in South Tyrol
}

\author{
Andrea Judith Lanthaler Manfred Mitterer \\ Department of Laboratory and Transfusion Medicine, Hospital 'Franz Tappeiner', Meran, Italy
}

\section{Key Words}

Transfusion medicine $\cdot$ Blood donation · Blood products

\begin{abstract}
Summary
Transfusion medicine in South Tyrol is organized according to the recommendations of the Council of Europe and the Italian transfusion law. The transfusion system is centralized and consists of one regional competence center and further six hospital-based transfusion sections. Blood donations are carried out in all sections; the processing of blood components is performed in the regional transfusion center. All sections are equipped with a defined amount of blood components, and they all perform blood group typing as well as indirect Coombs testing. Special analyses are carried out in the regional transfusion center exclusively. A nationwide voluntary association manages recruitment and coordination of blood donors. Donors are exclusively voluntary and non-remunerated. Selection and testing of donors is based on Italian and European guidelines. Local committees ensure the safety of the clinical use of blood and derivatives in each hospital.
\end{abstract}

\section{Introduction}

South Tyrol is an alpine region in the north of Italy. It has an area of 7,400 $\mathrm{km}^{2}$ and a total population of 476,023 (2004). More than two thirds of the population is German-speaking $(68 \%)$; the second most used language is Italian (28\%), followed by Ladin (4\%). Within the whole population, the Ger-

\section{Schlüsselwörter \\ Transfusionsmedizin · Blutspende · Blutprodukte}

\section{Zusammenfassung}

Die Transfusionsmedizin in Südtirol ist entsprechend den italienischen Gesetzen und den Europäischen Richtlinien organisiert. Das Transfusionssystem ist zentralisiert und besteht aus einem regionalen Kompetenzzentrum und sechs weiteren Sektionen. In allen Sektionen werden Blutspenden durchgeführt; die Gewinnung von Blutprodukten erfolgt zentral. Alle Sektionen sind mit einer bestimmten Menge an Blutprodukten ausgestattet und führen die Bestimmung der Blutgruppe und den indirekten Coombs-Test durch. Spezielle Analysen werden ausschließlich im nationalen Transfusionszentrum durchgeführt. Die Koordination der Blutspender wird von einer landesweiten, freiwilligen Blutspenderorganisation übernommen. Als Blutspender kommen dabei ausschließlich freiwillige, nicht bezahlte Personen in Frage. Die Auswahl und Testung der Spender erfolgen gemäß italienischen und europäischen Empfehlungen. In allen Krankenhäusern garantieren lokale Komitees für die sichere Verwendung von Blut und Blutderivaten.

\begin{tabular}{ll}
\hline KARGER & ( ) 2006 S. Karger GmbH, Freiburg \\
$\begin{array}{l}\text { Fax +49 761 45207 14 } \\
\begin{array}{l}\text { E-mail Information@Karger.de } \\
\text { www.karger.com }\end{array}\end{array}$ & $\begin{array}{l}\text { Accessible online at: } \\
\text { www.karger.com/tmh }\end{array}$ \\
&
\end{tabular}

Dr. Manfred Mitterer

Department of Laboratory Medicine Hospital 'Franz Tappeiner'

Rossinistraße V, 39012 Meran, Italy

Tel. +39 0473 26-3082, Fax -4693

E-mail manfred.mitterer@asbmeran-o.it 


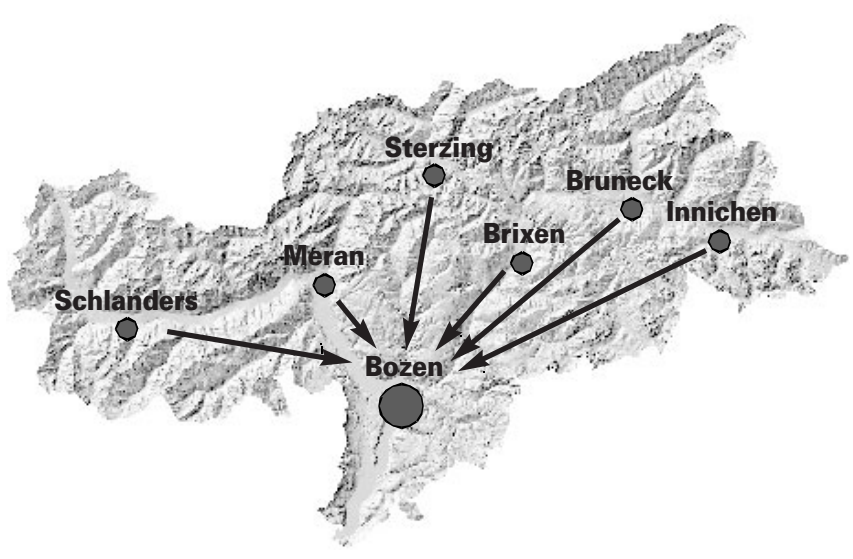

Fig. 1. The transfusion system of South Tyrol consists of a regional competence center (Bozen) and further 6 peripheral transfusion sections located in the respective hospitals (Meran, Schlanders, Sterzing, Brixen, Bruneck, Innichen).

dures are based on the recommendations of the Council of Europe [2] and the national transfusion law [3-6].

\section{Organization, Politics and Public Perception}

The transfusion system in South Tyrol is hospital-based and consists of seven sections (according to the seven local hospitals), the regional competence center and six peripheral transfusion sections (fig. 1). An expert committee consisting of transfusion specialists, administrative personnel of the ministry of health, and representatives of the voluntary association of blood donors (Associazione Italiana Volontari del sangue; AVIS) works out the annual demand for blood donations of the whole province. Special plans are elaborated for emergency cases. If necessary, blood donors can be mobilized immediately by e-mail, phone and local mass media due to the capillary organization system of the voluntary association of blood donors.

Blood donations are carried out in all seven sections. The collected units are transported to the regional transfusion center in refrigerated wagons. The production of blood components is centralized, and the regional transfusion center coordinates and compensates blood transfusions of the whole province. A possible surplus of components is given to other Italian regions with a scant supply of blood products.

The peripheral transfusion sections are part of the hospitals laboratory departments. They are all equipped with a standardized amount of blood components according to the distribution of the blood groups in the local population. In 1995 the 'type and screen' test has been introduced in the whole province; blood typing and indirect Coombs testing are carried out in all seven hospitals; special immunohematologic analyses are performed in the regional transfusion center.
Table 1. Number of blood donations in South Tyrol in 2005

\begin{tabular}{lc}
\hline Component & Number of collected units \\
\hline Whole blood & 24,000 \\
Plasma apheresis & 150 \\
Platelets apheresis & 1,000 \\
Total number & 25,150 \\
\hline
\end{tabular}

A regional committee consisting of transfusion specialists and nurses plans the central acquisition of transfusion-related reagents, material, and instruments. A uniform software for transfusion medicine is installed in all hospitals. This software program comprises all data regarding blood donors, recipients, and blood products of all seven blood blanks.

According to national guidelines [3-6], each hospital has a committee for the correct use of blood and blood products, in which transfusion specialists, physicians of the departments with an important transfusion activity, and nurses are represented. This transfusion committee meets at least once a year, and the local responsible has to give an account of the local transfusion activity and the correct use of blood and blood products.

In South Tyrol, the number of blood donations fits the demand, and the province is self-sufficient for red blood cell concentrates, plasma and platelet concentrates. The number of blood donations performed in South Tyrol in 2005 is given in table 1.

\section{Blood Donors}

Recruitment, promotion and coordination of blood donors is managed by the nationwide AVIS. Donors are exclusively voluntary and non-remunerated. The number of registered donors in South Tyrol is approximately 13,500. The annual turnover rate is nearly $5 \%$. Clinical selection of donors and criteria for temporary or permanent rejection correspond to Italian and European guidelines [2-6].

An informational meeting is hold monthly for all first-time donors. Using a standardized slide presentation, the responsible physician explains essential topics of blood donation, e.g. the donation process, the protection of the donor, and the protection of the recipient. Special notes are taken that donors are provided with accurate information on hepatitis and HIV transmission, so that those with any risk behavior (e.g. unsafe sex practices, drug abuse) will refrain from donating.

\section{Examination of First-Time Donors}

$\mathrm{X}$ ray chest examination, electrocardiogram and laboratory examination are performed for all donors, and a physician checks suitability. Suitable donors are further invited for an 
Table 2. General requests for blood donors

\begin{tabular}{ll}
\hline Age & $\begin{array}{l}\text { minimum } 18 \text { years, } \\
\text { maximum } 65 \text { years } \\
\text { upper limit for first-time } \\
\text { donors } 60 \text { years } \\
\text { minimum } 50 \mathrm{~kg}\end{array}$ \\
& $50-100$ beats $/$ minute, regular \\
Weight & \\
Pulse & $110-180$ \\
Blood pressure, mm Hg & $60-100$ \\
$\quad$ Systolic & \\
$\quad$ Diastolic & $\geq 12.5$ \\
Haemoglobin (before donatation), g\% & $\geq 13.5$ \\
$\quad$ Female donors & $450( \pm 10 \%)$ \\
$\quad$ Male donors & \\
Quantity of donation, ml & $\geq 180$ \\
Interval between donations, days & $\geq 90$ \\
$\quad$ Female donors & Male donors
\end{tabular}

appropriate interview and a clinical examination. The general requests for blood donors are summarized in table 2 .

\section{Examination of Regular Donors}

A clinical examination is performed for all donors once a year. In order to obtain information about the general health and the medical history, a questionnaire has to be completed and signed each time the donor attends to donate. Furthermore, a specially trained nurse, tests pulse, blood pressure, weight and pre-donation hemoglobin level. Donors are always provided with educational material containing up to date information about HIV, hepatitis and other potentially transmitted pathogens. Furthermore, the opportunity for self-exclusion is provided, and donors are always asked to inform the transfusion center about any posttransfusion infection. Hepatitis infections have to be reported even if occurring up to 6 months after donation.

The laboratory examinations that are performed in first-time donors and in regular donors (on each donation) are summarized in table 3; examinations that are performed in blood units are listed in table 4.

\section{Blood Components}

As described in the section 'Organization, Politics and Public Perception', the production of blood components is performed centrally in the regional transfusion center. All production steps are based on standard operating procedures (SOPs). Whole blood units are routinely leukodepleted using an in-line filtration system [7]. Accreditation for blood component production is planned for the next future.

The following blood components are obtained in the regional transfusion center:

- leukodepleted red blood cell concentrates,

- leukodepleted platelet concentrates,

- plasma
Table 3. Laboratory examinations of blood donors

\begin{tabular}{ll}
\hline First-time donors & On each donation \\
\hline Blood count & Blood count \\
PT and PTT & \\
Serum creatinine & \\
Blood glucose & \\
Total protein & \\
Serum protein electrophoresis & \\
Serum ferritin & \\
Triglyceride & \\
Cholesterol &
\end{tabular}

- fibrin sealant,

- stem cells/bone marrow for transplantation.

\section{Red Blood Cell Concentrates}

Various red blood cell concentrates are available for routine and special indications: leukodepleted red blood cell concentrates for all patients, saline-washed red blood cell concentrates for patients with allergic reactions against plasma, irradiated red blood cell concentrates for immunodeficient patients and for patients with special onco-hematological therapy. For patients with rare erythrocyte antigen pattern, red blood cell concentrates can be cryoconserved.

\section{Platelet Concentrates}

Platelet concentrates are recovered from 6 buffy coats of whole blood donations. For special indications (e.g. patients with leukemia) platelet concentrates are obtained by apheresis procedures.

\section{Plasma}

Fresh frozen plasma is produced using the standard technique. No virus inactivation (e.g. using methylene blue) is performed actually. A small part of plasma is collected by apheresis donations; because of the elevated costs, this procedure is diminishing.

Plasma which is not used for direct transfusion is delivered to a biotechnology company specialized in the production of hemoderivatives. According to a strategic partnership between the company and the local ministry of health, the hospitals in South Tyrol receive manufactured hemoderivatives such as antithrombin III, immunoglobulins or factor VIII for therapeutic use in exchange.

\section{Compatibility Testing}

Analyses are always double-checked, and blood typing results are compared with previous data. For compatibility testing, a 'type and screen' procedure is carried out on two independent samples. An additional compatibility testing between donor red blood cells and recipient's serum is done in cases with irregular antibodies, only. 
Table 4. Laboratory examinations of blood units

\begin{tabular}{ll}
\hline Unit (first-time donor) & Unit (each donation) \\
\hline ABO blood group testing (direct and indirect test) & ABO blood group testing (direct test) \\
Rh D group testing (complete testing) & Rh D group testing (confirmation) \\
Kell group testing & \\
Screening for irregular antibodies & ALT \\
ALT & syphilis (TPHA) \\
Syphilis (TPHA) & anti-HIV 1 and 2 \\
Anti-HIV 1 and 2 & HBsAg \\
HBsAg & anti-HCV \\
Anti-HCV & HCV NAT (HIV NAT and HBV NAT planned) \\
HCV NAT (HIV NAT and HBV NAT planned) & \\
\hline
\end{tabular}

\section{Screening for Infectious Agents}

As shown in table 4, all units are routinely screened for ALT, anti-HIV 1 and 2, HBsAg, anti-HCV, syphilis (TPHA); additionally HCV nucleic acid testing (NAT) is done. Final components are released only when all quality controls have been completed. Donors who are found positive for infectious markers are retested using the same assay. If the repeat test is positive, additional tests are performed in an appropriate laboratory in order to confirm the positive results. Confirmed positive donors are counseled and excluded from further donation. All repeatedly and confirmed positive results are collected.

\section{$N A T$}

In South Tyrol the use of NAT for HCV RNA screening was introduced in routine in 2001. In Italy HCV RNA screening became mandatory by law in 2002. Introduction of HBV DNA and HIV RNA screening is planned for 2007. They are currently not mandatory in Italy.

\section{Quality Control}

Production, storage and transport of all blood units and blood products are carried out under stringent controls which correspond to national and European guidelines [2-6]. All methods are based on SOPs. For laboratory analysis only validated tests are used. Internal and external run controls are included regularly. Accreditation for blood component production is planned for the next future.

Storage conditions of blood units and components are monitored continuously. All freezers and refrigerators are equipped with temperature recording and alarm devices. Equipment such as centrifuges, refrigerators and freezers of the transfusion sections and the clinical departments is under the control of the officer for blood transfusion of every hospital. All equipment is maintained and supervised by the engineering staff of the ministry of health responsible for medical equipment. Personnel receive appropriate training according to the CME program.

\section{Labeling, Registration and Storage}

Labeling is performed according to code UNI 10529. The following information appear on every unit: name and address of the producer, unique identity number, blood component, volume, $\mathrm{ABO}$ and $\mathrm{RhD}$ group, date of expiry, temperature of storage. Furthermore, the sentence: 'The component must not be used for transfusion if there is hemolysis or other evident abnormalities' is printed on the labels.

Registration and storage of data is carried out using a standardized, traceable computer-aided system which permits to reconstruct the course of every single donation from the time of collection until use. The following records are maintained for 30 years: documentation regarding the blood donation from the time of collection until use, written informed consents, results of laboratory testing. Data regarding blood group testing, presence of irregular antibodies, compatibility testing as well as transfusion complications is maintained for 15 years. Data regarding storage temperature of blood and products and quality controls regarding all methods, reagents, and equipment are maintained for 1 year.

\section{Clinical Quality Assurance}

An expert committee of transfusion specialists has elaborated guidelines for the correct use of red blood cells, platelet concentrates, and plasma. These guidelines are available in each hospital.

Requests for blood components must always be controlled by a transfusion specialist. Both the medical doctor who required the blood components and the transfusion specialist therefore share the responsibility for the correct indication. A recently conducted study showed that about $3.5 \%$ of all requests do not fit the criteria for a correct transfusion indication. In these cases the transfusion specialist has to intervene, and the case has to be discussed with the clinician.

Standardized request forms exist for special components such as immunoglobulins, albumin, prothrombin complex concentrate, antithrombin III concentrate, factor VIII, etc. Both the responsible transfusion specialist and a pharmacist check the correct request for these components regularly. 


\section{Autologous Transfusion}

In order to reduce the risk of transfusion-related complications and to enhance the supply of blood, autologous transfusions and intraoperative blood salvage (IBS) are promoted. For all surgical procedures where transfusion is likely, pre-operative autologous blood donations (PABD) are offered to the patient. Indications for PABD and IBS procedures are shown in table 5.

\section{Specific Topics}

The Italian law provides that blood donors are used for epidemiological studies. In 2004 the blood banks of South Tyrol, East Tyrol and North Tyrol have conducted a study in order to analyze the presence of different pathogens (FSME, Borrelia, Babesia, Anaplasma, West Nile virus and Hantavirus) among the total population [8]. In South Tyrol about $5 \%$ of all blood donors were enrolled into the study.

Primary goals of the study were:

- to provide basic information for medical practitioners about the spread of these infectious diseases in South Tyrol,
Table 5. Indications for autologous transfusion and intraoperative salvage procedures

\begin{tabular}{lll}
\hline & PABD & IBS \\
\hline Major vascular surgery & + & + \\
Primary hip replacement & + & + \\
Revision, hip replacement & + & + \\
Total knee replacement & + & - \\
Major spine surgery with instrumentation & + & + \\
Radical prostatectomy & + & +
\end{tabular}

PABD = Pre-operative autologous blood donations;

IBS = intraoperative blood salvage.

- to analyze the prevalence of antibodies ( $\operatorname{IgG})$ specific for the named pathogens in the healthy population,

- to determinate whether a vaccination program against FSME should be started in South Tyrol,

- to determine whether screening of blood donators for Babesia, Borrelia, and West Nile virus is indicated.

The study showed no increased prevalence of the pathogens under investigation in South Tyrol, and therefore no specific measures for transfusion medicine are required.

\section{References}

1 www.eurac.it/org/geneticMedicine/ geneticMedicine/index_de.htm.

2 Guide to the Preparation, Use and Quality Assurance of Blood Components. Recommendation (No. R895) 15, 11th ed. Strasbourg, Council of Europe Publishing, 2005.

3 Disciplina per le attivita' trasfusionali relative al sangue umano ed ai suoi componenti e per la produzione di plasmaderivati. Legge 4 Maggio 1990, n. 107. Gazzetta Ufficiale della Repubblica Italiana N. 108 dell' 11 Maggio 1990, Roma.
4 Protocolli per l'accertamento della idoneità del donatore di sangue ed emocomponenti. Decreto Ministeriale 3 Marzo 2005. Gazzetta Ufficiale della Repubblica Italiana N. 85 del 13 Aprile 2005, Roma.

5 Misure dirette ad escludere il rischio di infezione da HIV2 da trasfusione di sangue e somministrazione di emoderivati. Decreto Ministeriale 30 Dicembre 1992. Gazzetta Ufficiale della Repubblica Italiana N. 9 del 13 Gennaio 1993, Roma.

6 Misure dirette ad escludere il rischio di infezioni epatiche da trasfusione di sangue. Decreto ministeriale 21 Luglio 1990. Gazzetta Ufficiale della Repubblica Italiana N. 195 del 22 Agosto 1990, Roma.
7 Ferrer F, Rivera J, Corral J, Gonzalez-Conejero R, Vicente V: Evaluation of leukocyte-depleted platelet concentrates obtained by in-line filtration. Vox Sang 2000;78:235-41.

8 Kreidl P, Walder G, Morosetti G. Seroprävalenz verschiedener durch Zecken, Mücken und Nagetiere übertragbarer Erkrankungen in Nordtirol, Osttirol und Südtirol. Studie TIMO. Autonome Provinz Bozen-Südtirol, Veröffentlichungen 2005. 